\title{
ТРИЕДИНАЯ ПАССИОНАРНО-ЭТНИЧЕСКАЯ СТРУКТУРА ОБЩЕСТВА КАК ПРЕДМЕТ ВЕДЕНИЯ СОЦИОЛОГИИ И СОЦИАЛЬНОЙ ФИЛОСОФИИ
}

Аннотация: В работе показано, что соииология, а за ней и соииальная философия являются производными западноевропейской христианской изивилиаџии и поэтому восприняли от неё черты раџионализма, соџиоцентризма и классовой структуры общества.

В содержании многих докладов на Третьем Российском философском конгрессе (2002) показана некорректность социоцентризма и связанной с ним манипуляцию сознанием, а также звучал призыв $к$ этноцентризму.

На основании теории этногенеза, разработанной Л. Н. Гумилевым, автор обосновывает триединую пассионарно-этническую структуру общества, которая, по мнению автора, должна стать основным предметом ведения социологии и социальной философии. Часть вопросов, которыми занимается соииология, должны перейти к фундаментальной культурологии.

Ключевые слова: Сочиология, сочиальная философия, социальная реальность, пассионарно-этническая структура общества, сочиоцентризм, манипуляиия сознанием, этноцентризм, пассионарная энергия, предмет ведения, культурология

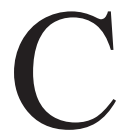
оциология возникла в западноевропейской христианской цивилизации, поэтому взаимосвязь христианского миросозерцания и социологической науки имеет не только исторические, но и смысловые корни. Глубоко символично и знаменательно, что уже Тропарь на Рождество Христово указывает на всеобщую разумность жизни: «воссия мирови свет разума». Христианская диалектика рассматривает общество с мифо-символической точки зрения. В мифе и символе она видит духовно-энергийную основу социального взаимодействия между людьми ${ }^{1}$. Такая онтология социологии, а за ней и социальной философии, вобрала в себя всю полноту западноевропейской рациональности и расчленения целостностей: «расчленяй и изучай» (в науке), «разделяй и властвуй» (в политике), что и породило бытие «двух культур» (Ч.Сноу) и недостаточность социально-философского описания проблемы взаимосвязи «природа - общество».

В русле социально-философского рассмотрения понятие социальной организации определено: сущность социальной организации образует доминантные

\footnotetext{
1 Бойко П. Е. Философско-методологические основания христианской социологии. //Рациона-лизм и культура на пороге третьего тысячелетия: Материалы Третьего Российского Философ-ского конгресса. Ростов н/Д: Изд. СКНЦ ВШ. 2002. T. 3. C. 38-39.
}

отношения коммуникации субъектов организации. Отсюда выделяются непосредственные их отношения (индивидуальные), опосредствованные несущностные (вещные) и опосредованно сущностные отношения (свободных индивидуальностей). Такой подход естественно приводит к формированию синергийной модели социальной организации, рационально воплощающейся на семи уровнях ее существования - примитивном, манипулятивном, стандартизованном, конвенциональном, игровом, деятельном и духовном, - с соответствующими формообразованиями: толпа, корпорация, отряд, ассоциация, компания, коллектив и братство. Такие отношения можно полагать как нормативные.

Развитие социальной организации демонстрирует следующую социальную динамику: на уровне примитивизации «личное» полностью «растворяется» в «общественном»; на уровне манипуляции происходит «подавление» индивидуальности в соответствии c «правилами» жестко иерархивизированной системы; на уровне стандартизации индивидуальность «нивелируется» в соответствии с жесткой нормой функции; на уровне конвенции начинает действовать своего рода «общественный договор»; игровой уровень есть уровень зарождения личностного начала в виде свободной индивидуальности; уровень деятельностных отношений есть уровень таких объективных связей, где доминантой является образование творчески кон- 
структивного качества индивидуальности и, наконец, высшим уровнем развития социальной организации является уровень воплощения личности как самоценности, своего рода микрокосма².

Таким образом, манипуляции онтологически заложены в развитие социальной организации. Социальная практика фальсификации и социальные продукты: учение о гегемонии Антонио Грамши, психологическая доктрина и социодинамика культуры явились краеугольными камнями манипуляции сознанием ${ }^{3}$ [40, с. 61-82].

В недрах самой социальной философии факты фальсификации в неявной форме признаются, а чтобы смягчить их называют «заблуждениями». Природе заблуждений в социальном познании посвящен раздел книги ${ }^{4}[41$, с. 25-36], в котором дается понятие заблуждения, рассматриваются заблуждения в социальном познании и вопросы познания социальных заблуждений, объективные и субъективные причины заблуждений в социальном познании. Приводится типология социальных заблуждений: социальные иллюзии; обыденные заблуждения, возникающие в результате дезинформации или даже заведомой лжи, прямого обмана; ошибки - теоретические и практические; опредмеченные социальные заблуждения, связанные идеологическим компонентом общественного сознания; заблуждения в социальных теориях, претендующих на объективноистинное знание, являются продуктом незрелой общественной практики, неразвитого познания и деформированных социальных отношений.

В современной социологической науке существует ряд концепций организационных структур, в которых отразились спорные моменты, касающиеся сущности понятия «социальная организация», различных теорий организации. Попытки определить социальную организацию через объекты (система) или субъекты (группа индивидов) породили принципиальные противоречия, которые и нашли свое отражение в исследовании проблем организационных структур. Различия в понимании механизма и логики организацион-

${ }^{2}$ Васильченко В.П. Социальная организация сквозь призму философской рефлексии (синер-гийный аспект). Там же. С. 48-49.

${ }^{3}$ Кара-Мурза С.Г. Манипуляция сознанием. - М.: Изд-во ЭКСМО-Пресс, -2001.

${ }^{4}$ Коллективная монография: «Философские раздумья: проблемы настоящего и будущего». - Ставрополь, 1997. 171 с. ной структуры прослеживаются на протяжении всего существования теории организации. Они восходят к противопоставлению рационально-искусственной и естественно-эволюционной моделей организации. С тех пор появилось множество разноплановых подходов, описываю-щих механизм и логику структурных изменений в организации. Противопоставляются, главным образом, две модели экзогенная (инвайронментальная) и эндогенная, которые опии-сывают процессы в терминах открытых и закрытых систем ${ }^{5}$ [42].

Организационные структуры социологии и социальной философии, их противоречия непосредственно связаны с некорректным определением социального пространства. В этой связи А. И. Бобков поставил вопрос о необходимости этноцентризма в социальной философии. Современный характер развития социологии и социальной философии свидетель-ствует о том, что многие проблемы генезиса социальных институтов объяснялись по принципу позитивного мировосприятия, который может быть обозначен как «факт, объясненный фактом» и из рассмотрения исключалось ряд социальных субъектов, которые считались не участвующими в создании моделей социальной реальности в силу «овеществления» социального бытия.

Таким образом, из социальной реальности исключались целые пласты знаний о ней, исходящие из того принципа, что помимо фактов есть еще мировоззренческие модели, которые в состоянии дать не менее важные аспекты осмысления происхождения социальных институтов. Одним из слоев социального бытия является проблема существования такого «воображаемого сообщества», как этнос, который является зародышем иного воображаемого сообщества «наций». Изучая этнос сквозь призму историографии, мы изучаем не этническое, а национальное самосознание, а значит, укладываем «этнос» в привычные идеологические и научные схемы. Мы имеем дело с нацией, а считаем ее этносом, что является фальсификацией ${ }^{6}$ [43]. Пушкинская ремарка: «Народ безмолвствует!» во многом подчеркивает всю драму исключения этноса из процессов, связанных с осмыслением социальной реальности.

\footnotetext{
5 Докукина Е. Ю. Роль социальных организаций в управлении. //Рационализм и культура на пороге третьего тысячелетия: Материалы Третьего Российского Философского конгресса. Ростов н/Д: Изд-во СКНЦ ВШ. 2002. Т. 3. С. 58-59.

${ }^{6}$ Бобков А. И. К вопросу о необходимости этноцентризма в социальной философии. Там же. Т. 3. С. 36-37.
} 


\section{Политика и общество 1 (97) • 2013}

Но, даже включая этнос в модели социальной реальности ${ }^{7}$, некорректно включать его в социальную структуру, фальсифицируя определение этноса как «исторически сложившийся вид социальной общности людей», тем самым фактически провозглашая социоцентризм. Более корректной является постановка вопроса о необходимости этноцентризма в социологии и социальной философии, понимая его как самобытное, самодостаточное осмысление социальной реальности, где процесс социогенеза описан в привычных категориях этнического самосознания. Этноцентризм нельзя путать с национализмом и цивилизационным монизмом 6 .

Е. В. Пашинцев отмечает: «Социологическая мысль до сих пор не сумела выделить социальную реальность в чистом виде. В основе этого затянувшегося кризиса (см.: СОЦИО-ЛОГОС. Вып. 1. 1991) лежат, по мнению автора, две концептуальные причины. Причина социально-философская: до сих пор в теоретическом сознании господствует мировоззрен-ческая парадигма с ее христианской дихотомией материального и идеального. Наличие всего лишь двух измерений социального пространства порождает “плоскую” социологическую картину мира. В социально-философском плане эта плоскостная парадигма приводит к тому, что общественные отношения либо “материализуются" (исторический материализм), либо “идеализируются” (все основные разновидности исторического идеализма)» ${ }^{8}$.

И далее: «Чисто теоретическая причина кризиса заключается в том, что категория деятельности еще не обрела свой полноценный социологический статус, выступая, по-прежнему, как абстрактный общефилософский критерий разделения природы и общества. Между тем основное назначение категории «деятельность» состоит в том, чтобы теоретически фиксировать фундаментальный слой исторической реальности - производство людьми своих общественных отношений» ${ }^{8}$.

Н. Жогова рассматривает выживание как основу массообразования и осуществления отношений вла-

${ }^{7}$ Гориков В. А., Медведев Н. П., Агамов А. А., Клочко Ю. Н., Пржиленский В. И., Рабчевская А. К. Основы философии (Учебник для вузов).- Ставрополь: Издат-во Ставропольского университета, 1996.-217 с. С. 138-139.

${ }^{8}$ Пашинцев Е.В. Границы современного социологического дискурса. //Рационализм и культура на пороге третьего тысячелетия: Материалы Третьего Российского Философского конгресса. Ростов н/Д: Изд-во СКНЦ ВШ. 2002. Т. 3. С. 116-117. сти и сценарий разыгрывания социального действа как манипулирования ими. Социология, став прислужницей идеологизированной Системы, выработала и специфические методы исследования «социальной статистики, социального моделирования, социологические методы исследования», легко поддающиеся фальсификации; подменила проблему выживания человечества вопросом о выживании человека в Системе9.

Марксистско-ленинское учение буквально «вбивали» в головы людей, в их подсознание. Социальная философия, став прислужницей Системы, внесла свою лепту в этот процесс оболванивания общества. Вольно или невольно, социальная философия стала объективно на путь фальсификации, как социального пространства, так и методов социологических исследований. А поскольку догмы живучи, то не так просто их перебороть и вернуться с дороги, на которой пар расходуется не на движение вперед, а на одни лишь гудки, имитирующие движение, на магистральный путь развития человечества. Но выбора нет: либо продолжать издавать одни лишь гудки, либо, переборов себя, выйти на широкую дорогу созидания и эволюционного развития.

Новейшее учебное пособие по социальной философии ${ }^{10}$ хотя и декларирует отказ от крайностей марксизма и идеализма и делает попытку «конвергенции, синтеза, итерации» их в социально-философский реализм, но на практике демонстрирует рецидив фальсификации, приписывая Гегелю открытие закона отрицания отрицания, хотя категория «снятие» у Гегеля ${ }^{11}$ имеет совершенно другой смысл.

Фактически, не поняв Гегеля ${ }^{12}$, делается попытка реанимации марксизма.

В этой связи В. Н. Самородов ${ }^{13}$ остро поставил вопрос о месте социальной философии в системе философского знания. По этому поводу автор пишет:

\footnotetext{
9 Жогова Н. Социальное как принцип взаимодействия массового и власти (Проекция концепции Элиаса Канетти на современные размышления). Там же. Т. 3. С. 63-65.

${ }^{10}$ Соколов С.В. Социальная философия: Учеб. пособие для вузов. - М.: ЮНИТИ-ДАНА, 2003. - 440 с.

${ }^{11}$ Таранов П.С. Мудрость трех тысячелетий. - М: ООО «Издательство АСТ», 1997. - 736 с. С/ 687/

${ }^{12}$ Корень P.В. Непонятый Гегель. //Рационализм и культура на пороге третьего тысячелетия: Материалы Ш Российского Философского конгресса. - Ростов-на-Дону, 2002. Т. 1. С. 131.

13 Самородов В.Н. Социальна философия в системе философского знания: от социальной метафизики к социальной антропологии. Там же. Т. 3. С. 133.
} 
«1. Одной из основных проблем является проблема определения предметного статуса социальной философии. Самоопределение социальной философии связано с поиском своего места в системе философского знания, причем претензия на философичность должна сочетаться с несводимостью социальной философии к другим областям знания (например, к моральной философии или теоретической социологии). Следует отметить, что социальная философия как самостоятельный раздел философского знания сформировалось лишь в Новое время. До этого социально-философская проблематика присутствовала в морально-этической (Ю.В.Перов).

2. В социальной философии Нового времени можно выделить две основные тенденции: социальная метафизика и социальная антропология.

3. Социальная метафизика ориентируется на выявление предельных оснований социальной реальности и осмысление того, как эти основания себя развертывают, проявляют в мировой истории и общественной жизни. Эти основания - плод умозрения, очень часто - авторских пристрастий. Выявленное основание задает систему категорий и стратегию постижения обцества. Общество раскрывается через категориальное описание, что на первый план выводит гносеологическую проблематику. Главное не социальная реальность, а система ее описания.

4. Социальная антропология рассматривает общество как манифестацию субъекта. На первый план выходит социальная онтология. Наиболее ярко социальная антропология заявила о себе в XX веке. Однако переход от социальной метафизики к социальной антропологии просматривается уже у Руссо (внес антропологический крен в понимание природы человека, которая до него понималась как, прежде всего, вневременная сущность). Кант, как представляется, усилил антропологический акцент в понимание общества. Что касается XX века, то здесь на первый план выходит интерес к человеку и модусом его существования, одним из которых является общество ${ }^{13}$.

Авторы ${ }^{14}$ поднимают важный вопрос методологии анализа социальной структуры. В частности, они отмечают: «Одной из проблем, с которыми приходится сталкиваться при анализе социальной структуры, - неоднозначность подхода к выбору единиц анализа и самой технологии. Для характеристики социальной структуры общества в социологии традиционно используются два понятия: «социальный слой» или страта и класс. Экономический контекст проступа- ет при употреблении термина «класс» и в современной западной социологической литературе... Наряду с классовой парадигмой в рамках современной отечественной социологии развивается и противоположный подход, именуемый стратификационным. Многие российские ученые считают классовое деление общества нецелесообразным и неприменимым в нынешних условиях. Их аргументы в основном сводятся к тому, что марксистские авторы, употребляя такой термин как «класс» стремятся, прежде всего, обозначить факт антагонизма, противоположности интересов больших общественных групп, выделяя элементы дезинтеграции, внутренних антагонизмов, тогда как дифференциация предполагает целостность общества, его функциональную неразделимость. В рамках своих исследований данные ученые противопоставляют классовому подходу стратификационный, считая, что именно понятие «социальная стратификация» позволяет описать неравенство между группами людей, определить социальное неравенство между ними, показать иерархию этого неравенства» ${ }^{14}$.

Авторы работы считают, что обе выше обозначенные концепции (классовая и стратификационная) имеют право на существование. Они констатируют, что в настоящее время очень популярны исследования, развивающиеся в рамках симбиоза марксистской и стратификационной концепций. Например, многие современные сторонники марксистской теории классов отказались от идеи растущей общественной поляризации. И далее авторы ${ }^{14}$ пишут: «Мы разделяем подход к данной проблеме известного отечественного социолога Ф. Р. Филиппова, который настаивает на том, что синтез классовой и стратификационной моделей социальной структуры на основе вычленения в научном анализе реально существующих классов, слоев и других социальных групп должен способствовать построению достаточно “объемной”, а не однолинейной модели социальной структуры, имеющей прочную эмпирическую базу».

Дефиниция «достаточно объемной» автору представляется излишне искусственной, аналогичной искусственному осеменению, применяемому для уже стельных животных, а «полубеременных» в природе не бывает. Как в таком случае можно иметь «прочную эмпирическую базу»? Здесь уместно еще раз приве-

\footnotetext{
${ }^{14}$ Самығин С.И., Самызин П.С. Классы или слои? (К проблеме методологии анализа социальной структуры). Там же.
} Т. 3. C. 134. 


\section{Политика и общество 1 (97) • 2013}

сти утверждение А.Ф.Бугаева: «На плоскостной фигуре в виде треугольника философия зациклилась на 2,5 тысячи лет. Пора пойти дальше и ввести объемные фигуры ${ }^{15}$.

Приведенный выше анализ методологической и практической деятельности социологии и социальной философии свидетельствует о следующем: вопервых, о их заблуждениях относительно социоцентризма; во-вторых, о некорректном определении социальной реальности и социального пространства; в-третьих, о многочисленных недостаточно успеш-ных попытках разрешения противоречий марксисткой теории классов через социальную организацию, социальную структуру, социальный слой, социальную стратификацию и т.д. Однако все эти социальные объекты пригодны для «внутреннего употребления», в лучшем случае, для анализа статики процесса (классификации), фиксирующей состояния, и совершенно не пригодны для описания динамики (систематики) развития общества. А тем более, непригодны для анализа и синтеза проблемы взаимосвязи системы «природа - общество», имеющей разные уровни общности и характера развития.

Между тем, многие из затронутых вопросов системно и методологически достаточно корректно разрешены в работах Л. Н. Гумилева ${ }^{16},{ }^{17}$. Однако многие авторы работ, учебников и учебных пособий по социологии и социальной философии высокомерно стараются их не замечать, а в лучшем случае, уделяют им всего несколько строк. Печальный симптом!

По мнению автора, основным вопросом (предметом ведения) социологии и социальной философии должен стать вопрос этно-пассионарной структуры общества, ибо только через нее по-разному (тройственно) проявляется деятельный принцип, определенный Л. Н. Гумилевым как энергия пассионарности. Именно эта энергия - пассионарность и растрачивается в процессе этногенеза, во много определяя развитие общества и его взаимосвязь с природой. Она уходит на создание культурных ценностей и политическую деятельность; управление государством и написание книг, ваяние скульптур и территориальную

\footnotetext{
${ }^{15}$ Бугаев А.Ф. Введение в единую теорию мира .- М.: Белые альвы, 1998. С/ 44/

${ }^{16}$ Гумилев Л.Н. Этногенез и биосфера Земли. - М.: Танаис ДИ-ДИК, 1994.-

${ }^{17}$ Гумилев Л.Н. Конец и вновь начало. - М «Институт ДИДИК», 1997. -
}

экспансию, на синтез новых идеологических концепций и строительство городов.

Любой такой труд требует усилий сверх тех, что необходимы для обеспечения нормального существования человека в равновесии с природой, а значит, без пассионарности ее носителей, вкладывающих свою энергию в культурное и социально-политическое развитие своей системы, никакой культуры и никакой политики просто не существовало бы. Но социальная философия, искусственно создав принцип социоцентризма, пытается возвыситься над Природой, элементом которой является человеческое общество, фактически исключает из социального пространства этнос, подменяя его национальностью, что не равнозначно и поэтому методологически некорректно.

Люди объединяются по принципу комплиментарности. Комплиментарность - это неосознанная симпатия к одним людям и антипатия к другим, т.е. положительная и отрицательная комплиментарность. Когда создается первоначальный этнос, то инициаторы этого возникающего движения подбирают себе активных людей именно по этому комплиментарному признаку - выбирают тех, кто им просто симпатичен. «Иди к нам, ты нам подходишь» - так отбирали викинги юношей для своих морских походов. Но за этим подсознательным выбором скрывается вполне материальное физическое явление - взаимодействие энергоинформационных полей, создающих гармонию у симпатизирующих особей. Как только принцип отбора по комплиментарности заменялся принципом всеобцности, система испытывала страшный удар и деформировалась ${ }^{16}$. Но комплиментарность на уровне культурного типа всегда умозрительна. Обычно она выражается в высокомерии, когда всех чужих и не похожих на себя людей называют «дикарями». Это результат пульсирующего развития, имеющего две противоположности, отраженного в культуре.

Итак, рождению любого социального института предшествует объединение какого-то числа людей, симпатичных друг другу. Начав действовать, они вступают в исторический процесс, сцементированные избранной ими целью (символом) и исторической судьбой. Как бы не сложилось их будущее, общность судьбы - «условие, без которого нельзя». Такая группа может стать разбойничьей бандой викингов, религиозной сектой мормонов, орденом тамплиеров, буддийской общиной монахов, школой импрессионистов и т. п., но общее, что можно вынести за скобки, - подсознательное взаимовлечение (коллективное бессозна- 
тельное), пусть даже для того, чтобы вести споры друг с другом. Поэтому эти зародышевые объединения Гумилев назвал консорциями. Не каждая из консорций выживает, большинство при жизни основателей рассыпаются, но те, которым удается уцелеть, входят в историю общества и немедленно обрастают социальными формами, часто создавая традицию.

Те немногие, чья судьба не обрывается ударами извне, доживают до естественной утраты повышенной активности, но сохраняют инерцию тяги друг к другу, выражающуюся в общих привычках, мироощущении, вкусах. Эту фазу комплиментарного объединения Гумилев назвал конвиксией. Она уже не имеет силы воздействия на окружение и подлежит компетенции не социологии, а этнографии, поскольку эту группу объединяет быт. В благо-приятных условиях конвиксии устойчивы, но сопротивляемость среде у них стремиться к нулю, и тогда они рассыпаются среди окружающих консорций.

Взаимодействия культуры (творения рук человеческих и разума) и этногенеза (феномена природы) прослеживается уже на первых двух его фазах. В фазе подъема складывается, а в акматической фазе кристаллизуется оригинальный для каждого случая $\mathbf{c m e -}$ реотип не только поведения, но и мировосприятия и мироосмысления: то, что может быть названо кульмурным типом. Разумеется, что и здесь не обходится без энергии в форме «пассионарности», так как для того, чтобы выработать новую, ни на что не похожую систему взглядов и воззрений, нужны огромные затраты пассионарной энергии, пожалуй, не меньше, чем для освободительных и завоевательных войн.

На практике процессы этногенеза подменяются состояниями (гражданскими, экономическими, политическими, техническими и т. д.). На самом же деле при наложении на корпускулярную этническую систему жесткой (социально-политической, экономической, технической) системы происходит замедление этнических процессов (и соответствующих фаз полного цикла этногенеза), но при этом повышается их устойчивость от агрессии соседних этносов другого суперэтноса с другим стереотипом поведения.

Из этого следует, что анализ познания, управления и развития суммарного (интегрированного) процесса и прогнозирование его хода следует производить не по социально-политическим, экономическим и т. д. критериям, а по критериям процесса этногенеза, с учетом воздействия налагаемой жесткой системы (систем).
Системные связи в этносе, а вместе с ними и единство этноса поддерживаются геобиохимической энергией живого вещества биосферы, эффект, который на этническом уровне организации биосферы описан Л. Н. Гумилевым, как явление пассионарности ${ }^{17}$. Пассионарность - поведенческий признак, воспринимаемый сторонним наблюдателем как непоборное стремление к намеченной цели, пусть даже иллюзорной, но для достижения которой носители ее - пассионарии - не жалеют как собственный жизни, так и жизни своего потомства. Психологически пассионарность проявляется как импульс подсознания, противоположный инстинкту самосохранения, как индивидуального, как и видового.

В зависимости от соотношения пассионарного импульса (Р) и инстинкта самосохранения (J) Гумилевым описано три характерных поведенческих mипа: а) пассионарии (P>J); б) гармоничные люди $(\boldsymbol{P}=\boldsymbol{J})$; в) субпассионарии $(\boldsymbol{P}<\boldsymbol{J})$. В каждом из описанных типов имеются по четыре состояния: а) пассионарии: пророки, нестяжатели, созерцатели (в смысле монахи), искусители; б) гармоничные люди: деловые люди, авантюристы, ученые люди, творческие люди; в) субпассионарии: обыватели, бродяги - солдаты, преступники, честолюбивцы.

Пассионарии возникают в этносе в результате мутации, а точнее, микро-мутации, меняющей что-то в гормональной системе организма и тем самым создающая новый поведенческий признак. Человек остается самим собой, но ведет себя по-другому. Мутация никогда не захватывает всей популяции. Мутируют отдельные особи и по-разному. Но явные уроды быстро устраняются естественным отбором, а для устранения мутантов-пассионариев необходимо около 1200 лет, причем они ухитряются оставить после себя следы своих деяний: здания, поэмы, картины, рассказы о своих подвигах, технические изобретения и моральные нормы. Если мутант абсорбирует больше энергии, то он должен истратить, а путь к этому только один - деяния. Но за деяниями следует упадок, когда пассионарии устраняются из этноса: около $80 \%$ гибнут в боях, завоеваниях или от непомерной работы. А уцелевшие возвращаются измотанными до предела или больными.

Но обязателен ли упадок? Да! Потому что наряду с пассионариями при мутации появляются субпассионарии - особи, абсорбирующие меньше энергии, чем количество, требующееся для уравновешивания потребностей инстинкта. Им все трудно, а желания их 


\section{Политика и общество $1(97) \cdot 2013$}

примитивны: поесть, выпить, поразвлечься с такой же женщиной. Таковы неаполитанские лаццарони, бродяги, описанные М. Горьким, подонки капиталистических городов, вымирающие племена Андаманских островов, которым лень наловить рыбу и нарвать в лесу плодов для любимых детей. Они лежат на берегу океана в ожидании парохода, а потом просят у приезжих туристов табаку, курят... и счастливы.

Субпассионарии существуют повсеместно, но очень различны. Близкие к оптимуму составляют кадры преступников и проституток. Те, кто слабее, становятся алкоголиками и наркоманами, а еще ниже стоят дебилы и кретины, у которых не хватает энергии даже на то, чтобы мечтать. Эти особи стоят за пределами нормы. Субпассионарии отнюдь не так безобидны, как может показаться. Для них характерна безответственность и импульсивность. Им ничего нельзя доверить, ибо ради минутного наслаждения они способны погубить важное дело, даже государственное или общественное. Они уничтожают ради сегодняшней выгоды кормящие ландшафты, обрекая на голод своих потомков. Любое будущее их не пугает, потому что они просто не в состоянии его вообразить. А тех людей, которые пытаются их вразумить, они убивают. Этот процесс особенно отчетливо виден в истории римской империи Ш-1У вв. не рабы, и не варвары, и не христиане погубили Рим. Это сделали любители цирковых зрелищ, бездельники, которых кормили даром. Ради чего истребляли население провинций и природу собственной страны - Италии, где дубравы не восстановились доселе. А склоны Апеннин заросли колючим маквисом.

Теперь становится понятной причинная связь между биохимической энергией живого вещества биосферы и отдельными системами - от организма до суперэтноса. Системы работают на биохимической энергии, абсорбируя (поглощая) ее из окружающей среды и выдавая излишек в виде работы (в физическом смысле). Оптимальное состояние, или гармоничность, системы, будь то один человек или многолюдный этнос, - это когда количество энергии, идущей на нужды самого организма и на пассионарность, равны. Тогда они уравновешивают друг друга, и система крепка.

Статистика фиксирует, что в этносе преобладают гармоничные особи; доли пассионариев в процентном отношении незначительны, но изменение их количества определяет геобихимическое состояние этноса как закрытой системы дискретного типа (по классифи- кации А. А. Малиновского $\left.{ }^{18}\right)$. Можно внести функцию состояние этнической системы - пассионарное напряжение (доля пассионариев в этносе), которое сопоставимо однозначно с частотой событий в этнической истории и числом подсистем в этносе (субэтносов). Пассионарное напряжение и направление его изменения определяют фазу этногенеза или возраст этноса.

Гуманитарная наука (а таковыми являются социология и социальная философия) дает многое узнать (сфера эмпирического знания), но не позволяет многого понять (сфера теоретического знания). Гуманитарий ограничен уровнем изучаемых авторов древности, а он был ниже, чем в XX в. Великий Гераклит сформулировал учение о вечной изменчивости: «Все течет, все изменяется, никто не может дважды войти в один и тот же поток, и к смертной сущности никто не прикоснется дважды!», а Зенон доказал, что движения нет, ибо Ахилл не может догнать черепаху. Оба умозрительных учения делают науку бессмысленной; гераклитовое - потому что описывать исчезающие и неповторяемые феномены невозможно, а зеноновское - потому что без движения к предметам изучения нельзя приблизиться для обследования их. Потому-то научное познание заменилось софистикой, и Горий имел право сформулировать свои три тезиса: 1) «Ничего нет!»; 2) «Если бы что-нибудь было, оно было бы непознаваемо!»; 3) «Если бы познание существовало, его было бы нельзя передать! ..». Тупик!

Как ни странно, все эти три философских подхода к науке дожили до XXI века, изменив формы, но не настолько, чтобы их было нельзя распознать: философские построения оказались неверными. Конечно, река и смертное тело изменяются, но в пределах законного допуска; повторное «прикосновение» к ним невозможно. Апогей Зенона, утверждавшего, что движение - лишь наше восприятие, поскольку оно немыслимо, опровергло появление дифференциального исчисления: оказалось, что движение, которое действительно - основа мироздания, не только наблюдаемо. Но и мыслимо. Причем непротиворечиво. Более того, как показано автором, жизнь является второй неотъемлемой стороной движения. Поэтому умозрительные софистские построения Зенона отрицаются самим фактом жизни самого Зенона.

\footnotetext{
${ }^{18}$ Малиновский A. А. Общие вопросы строения систем и их значение для биологии. //Проблемы методологии системного исследования. /Под редакцией И. В. Блауберга и др. - М.: 1970. С. $145-150$.
} 
Да, стабильными можно назвать те явления и предметы, которые изменяются медленно, но и тут нужно учитывать, что характер изменений определяется не столько видимостью такового, сколько диалектическими законами: переходом количества в качество, единством и борьбой противоположностей и т. д. Эти законы подсказывают необходимость учитывать, кроме линейного и вращательного, третий вид движения - колебательное, которое лежит в основе многих явлений, в том числе - этногенеза как явления природы и триалектики как высшей формы диалектики.

Поставим следующий вопрос: к компетенции какой науки - естественной или гуманитарной относится все то, что сказано выше о динамике этноса, обществе как этнической целостности с сопутствующими ей социальными институтами и пассионарно-этнической структуре общества? Для ответа, прежде всего, потребуется уточнить само понятие гуманитарных и естественных наук. Принято думать, что гуманитарные науки - это те, которые изучают человека и его деяния, а естественные науки изучают природу. Это деление неконструктивно и полно противоречий, делающих его бессмысленным. Медицина, физиология и антропология изучают человека, но не являются гуманитарными науками. Отсюда видно, что различие между гуманитарными и естественными науками не принципиально, а, скорее, стадиально. Да и как можно изучать человека - дитя природы - без обращения к внешней среде - самой природе.

Исходя из сказанного, легко заключить, что деление образов мышления, а тем самым наук, по предмету изучения неправомерно. Гораздо удобнее деление по способу подхода к получению первичной информации. Тут возможны два подхода: чтение книг или выслушивание сообщений (легенд, мифов и т. д.) и наблюдение, иногда с экспериментом. Первый способ соответствует гуманитарным наукам; второй естественным наукам, которые следует подразделить на математизированные и описательные. Математизированные имеют дело с символами; описательные - с феноменами. К числу последних относится география и биология.

Причина такого странного размежевания наук глубока. Но и она описана В. И. Вернадским, назвавшим ее «бессознательным научным дуализмом». Он разъясняет этот тезис так: «Под именем дуалистического научного мировоззрения я подразумеваю тот своеобразный дуализм... когда ученый-исследователь противопоставляет себя - сознательно или бессозна- тельно - исследуемому миру... Получается фантазия строго наблюдения ученым исследователем совершающихся вне его процессов природы как целого» ${ }^{19}$.

Научный дуализм, столь вредный в естественных науках, - наследие гуманитарных навыков, перенесенных в чуждую им область. Тут разница принципиальная. То, что гуманитарий рассматривает извне, то естествоиспытатель должен стараться рассмотреть изнутри, ибо сам находится в биосфере, потоке постоянных изменений. В этом потоке он видит больше, чем гуманитарий, для которого открыта только рябь на поверхности, но соучастие в планетарной жизни кончается с его неизбежной гибелью как всякого живого организма.

Как известно, все природные закономерности вероятностны и, следовательно, подчинены закону больших чисел. Значит, чем выше порядок - тем неуклоннее воздействие закономерностей на объект; и чем ниже порядок - тем более возрастает роль случайностей, а тем самым и степень свободы. Обобщив эти положения Л. Н. Гумилева, А. Л. Чижевского: «Чем ближе к Солнцу, тем ближе к истине» и математической декомпозиции уравнений, когда их меньше, чем неизвестных, автор вводит в науку, философию и практику Принцип (правило) поиска истины: «Чем шире обобщения, тем ближе к истине» ${ }^{20}$.

И в опыте ошибки возможны. Опыт может быть не чистым: данные могут быть подогнаны (артефакт) или не учтены все привходящие компоненты. Но все эти недостатки компенсируются большим числом наблюдений, где неизбежная ошибка лежит в пределах допуска. Иначе говоря, она столь мала, что ею не только можно, но и нужно пренебречь. Так возникают эмпирические обобщения ${ }^{21}$ - непротиворечивый комплекс сведений, по достоверности равный наблюдаемому факту. Если набрать их много, они будут поддаваться классификации, а в дальнейшем и систематизации. Этим путем в XIX в. пошла социально-экономическая история. И данные ее легли в основу исторического материализма, предмет которого - не отрывочные сведения летописцев, а объективная реальность со свойственной ей закономерностью.

19 Вернадский В. И. Избранные труды по истории науки. M., 1981. С. 39.

${ }^{20}$ Корень Р. В. Принцип поиска истины. //Материалы Пятой Международной конференции «Циклы». Том первый. Ставрополь, 2003. С. 120-121.

${ }^{21}$ Вернадский В. И. Соч. Т. 5: Биосфера. - М., 1960. С. 19. 


\section{Политика и общество 1 (97) • 2013}

В исторической географии и этнографии XIX в. такой постановки вопроса не было, потому что не было способов ее решения. Они появились лишь в середине XX в. Это были системный подход Л. Фон Берталанфи ${ }^{22}$ и учение В. И. Вернадского о биохимической энергии живого вещества биосферы ${ }^{23}$. Именно эти два открытия позволили сделать эмпирическое обобщение всех ранее установленных фактов и дать тем самым описательное определение категории «этнос». Установив характер движения материи в этногенезах. Тем самым гуманитарная историческая география и палеоэтнография превратились в новую естественную науку - этнологию, которая является одним из «мостов между науками» ${ }^{17}$.

По мнению автора, то же объективно должно произойти с социологией и социальной философией, которые должны «подружиться» с этнологией и сделать основным предметом своего ведения пассионарно-этническую структуру общества, освободившись от социоцентризма, фальсификаций социодинамики и порочных методов «социальных методов исследования», обретя статус этноцентризма.

При этом, по мнению автора, часть разделов социальной антропологии, социологии и социальной философии должны перейти к предмету ведения фундаментальной культурологии (по своему содержанию становящейся естественнонаучной философией культуры), обобщения которой шире. В частности, такие как природа и общество, основы философского анализа общества, общество как исторический процесс, проблема человека, культура и цивилизация, ценность и ее роль в жизни общества и человека, проблемы и перспективы современной цивилизации.

\section{Библиография:}

1. Берталанфи Л. Общая теория систем - критический обзор //исследование по общей теории систем. - м., 1969.

2. Бобков А. И. К вопросу о необходимости этноцентризма в социальной философии. //рационализм и культура на пороге третьего тысячелетия: материалы третьего российского философско-

\footnotetext{
${ }^{22}$ Берталанфи Л. Общая теория систем - критический обзор //Исследование по общей теории систем. - М., 1969.

${ }^{23}$ Вернадский В. И. Химическое строение биосферы Земли и ее окружения - М., 1965.
}

го конгресса. Ростов н/д: изд-во скнц вш. 2002.. T. 3. C. 36-37.

3. Бойко П. Е. Философско-методологические основания христианской социологии. //рационализм и культура на пороге третьего тысячелетия: материалы третьего российского философского конгресса. Ростов н/д: изд. Скнц вш. 2002. Т. 3. С. 38-39.

4. Бугаев А. Ф. Введение в единую теорию мира .м.: белые альвы, 1998. С/ 44/

5. Васильченко В. П. Социальная организация сквозь призму философской рефлексии (синергийный аспект). //рационализм и культура на пороге третьего тысячелетия: материалы ш российского философского конгресса. Ростов н/д: изд. Скнц вш. 2002. Т. 3. С. 48-49.

6. Вернадский В. И. Избранные труды по истории науки. - м., 1981. С. 39.

7. Вернадский В. И. Соч. Т. 5: биосфера. - м., 1960. С. 19.

8. Вернадский В. И. Химическое строение биосферы земли и ее окружения - М., 1965.

9. Горшков в. А., Медведев Н. П., Агамов А. А., Клочко Ю. Н., Пржиленский В. И., Рабчевская А. К. Основы философии (учебник для вузов).- Ставрополь: издатво ставропольского университета, 1996.-217 с.

10. Гумилев Л. Н. Этногенез и биосфера земли. - м.: танаис ди-дик, 1994.-

11. Гумилев Л. Н. Конец и вновь начало. - м «институт ди-дик», 1997. -

12. Докукина Е. Ю. Роль социальных организаций в управлении. //рационализм и культура на пороге третьего тысячелетия: материалы третьего российского философского конгресса. Ростов н/д: изд-во скнц вш. 2002. Т. 3. С. 58-59.

13. Жогова Н. Социальное как принцип взаимодействия массового и власти (проекция концепции элиаса канетти на современные размышления). Там же. Т. 3. С. 63-65.

14. Кара-Мурза С. Г. Манипуляция сознанием. - м.: изд-во эксмо-пресс, -2001.

15. Коллективная монография: «философские раздумья: проблемы настоя-щего и будущего». - ставрополь, 1997. $171 \mathrm{c}$.

16. Корень Р. В. Непонятый гегель. //рационализм и культура на пороге третьего тысячелетия: материалы третьего российского философского конгресса. - ростов-на-дону, 2002. Т. 1. С. 131.

17. Корень Р. В. Принцип поиска истины. //материалы пятой между-народной конференции «циклы». Том первый. - ставрополь, 2003. С. 120-121. 
18. Малиновский а. А. Общие вопросы строения систем и их значение для биологии. //проблемы методологии системного исследования. /под редакцией и. В. Блауберга и др. - м.: 1970. С. 145-150.

19. Пашинцев Е. В. Границы современного социологического дискурса. //рацио-нализм и культура на пороге третьего тысячелетия: материалы третьего российского философского конгресса. Ростов н/д: изд-во скнц вш. 2002. Т. 3. С. 116-117.

20. Самородов В. Н. Социальна философия в системе философского знания: от социальной метафизики к социальной антропологии. Там же. Т. 3. С. 133.

21. Самыгин С. И., самыгин п.с. Классы или слои? (к проблеме методологии анализа социальной структуры). Там же. Т. 3. С. 134.

22. Соколов С. В. Социальная философия: учеб. Пособие для вузов. - м.: юнити-дана, 2003. - 440 с.

23. Таранов П. С. Мудрость трех тысячелетий. - м: ооо «издательство аст», 1997. - 736 с. С ил. (звезды мировой философии).

\section{References (transliteration):}

1. Bertalanfi L. Obshchaya teoriya sistem - kriticheskiy obzor //issledovanie po obshchey teorii sistem. - m., 1969.

2. Bobkov A. I. K voprosu o neobkhodimosti etnotsentrizma v sotsial'noy filosofii. //ratsionalizm i kul'tura na poroge tret'ego tysyacheletiya: materialy tret'ego rossiyskogo filosofskogo kongressa. Rostov n/d: izdvo sknts vsh. 2002.. T. 3. S. 36-37.

3. Boyko P. E. Filosofsko-metodologicheskie osnovaniya khristianskoy sotsiologii. //ratsionalizm i kul'tura na poroge tret'ego tysyacheletiya: materialy tret'ego rossiyskogo filosofskogo kongressa. Rostov n/d: izd. Sknts vsh. 2002. T. 3. S. 38-39.

4. Bugaev A. F. Vvedenie v edinuyu teoriyu mira .- $\mathrm{m}$.: belye al'vy, 1998. C/ 44/

5. Vasil'chenko V. P. Sotsial'naya organizatsiya skvoz' prizmu filosofskoy refleksii (sinergiynyy aspekt). //ratsionalizm i kul'tura na poroge tret'ego tysyacheletiya: materialy sh rossiyskogo filosofskogo kongressa. Rostov n/d: izd. Sknts vsh. 2002. T. 3. S. 48-49.

6. Vernadskiy V. I. Izbrannye trudy po istorii nauki. m., 1981. S. 39.

7. Vernadskiy V. I. Soch. T. 5: biosfera. - m., 1960. S. 19.

8. Vernadskiy V. I. Khimicheskoe stroenie biosfery zemli i ee okruzheniya - m., 1965.
9. Gorshkov V. A., Medvedev N. P., Agamov A. A., Klochko Yu. N., Przhilenskiy V. I., Rabchevskaya A. K. Osnovy filosofii (uchebnik dlya vuzov).stavropol': izdat-vo stavropol'skogo universiteta, 1996.-217 s.

10. Gumilev L. N. Etnogenez i biosfera zemli. - m.: tanais di-dik, 1994.-

11. Gumilev L. N. Konets i vnov’ nachalo. $-\mathrm{m}$ «institut di-dik», 1997. -

12. Dokukina E. Yu. Rol' sotsial'nykh organizatsiy v upravlenii. //ratsionalizm i kul'tura na poroge tret'ego tysyacheletiya: materialy tret'ego rossiyskogo filosofskogo kongressa. Rostov n/d: izd-vo sknts vsh. 2002. T. 3. S. 58-59.

13. Zhogova N. S otsial'noe kak printsip vzaimodeystviya massovogo i vlasti (proektsiya kontseptsii eliasa kanetti na sovremennye razmyshleniya). tam zhe. t. 3. s. 63-65.

14. Kara-Murza S. G. Manipulyatsiya soznaniem. - m.: izd-vo eksmo-press, - 2001.

15. Kollektivnaya monografiya: «Filosofskie razdum'ya: problemy nastoya-shchego i budushchego». stavropol', 1997. $171 \mathrm{~s}$.

16. Koren' r. V. Neponyatyy gegel'. //ratsionalizm i kul'tura na poroge tret'ego tysyacheletiya: materialy tret'ego rossiyskogo filosofskogo kongressa. rostov-na-donu, 2002. T. 1. S. 131.

17. Koren' R. V. Printsip poiska istiny.//materialy pyatoy mezhdu-narodnoy konferentsii «tsikly». Tom pervyy. - stavropol', 2003. S. 120-121.

18. Malinovskiy a. A. Obshchie voprosy stroeniya sistem i ikh znachenie dlya biologii. //problemy metodologii sistemnogo issledovaniya. /pod redaktsiey i. V. Blauberga i dr. - m.: 1970. S. 145-150.

19. Pashintsev e. V. Granitsy sovremennogo sotsiologicheskogo diskursa. //ratsio-nalizm i kul'tura na poroge tret'ego tysyacheletiya: materialy tret'ego rossiyskogo filosofskogo kongressa. Rostov n/d: izdvo sknts vsh. 2002. T. 3. S. 116-117.

20. Samorodov v. N. Sotsial'na filosofiya v sisteme filosofskogo znaniya: ot sotsial'noy metafiziki $\mathrm{k}$ sotsial'noy antropologii. tam zhe. t. 3. s. 133.

21. Samygin s. I., samygin p.s. Klassy ili sloi? (k probleme metodologii analiza sotsial'noy struktury). Tam zhe. T. 3. S. 134.

22. Sokolov S. V. sotsial'naya filosofiya: ucheb. posobie dlya vuzov. - m.: yuniti-dana, 2003. - $440 \mathrm{~s}$.

23. Taranov p. S. Mudrost' trekh tysyacheletiy. - M: OOO «Izdatel'stvo Ast», 1997. - 736 S. S IL. (Zvezdy Mirovoy Filosofii). 